\title{
STUDY THE APPLICATION OF ORGANIC MANURE AND WASTE WATER AND ITS EFFECT UPON SOIL AND WATER POLLUTION
}

\author{
Aram Suleiman \\ Ph.D. Student \\ University of Agronomical Sciences and Veterinary Medicine Doctorate school in Bucharest. \\ Bucharest, Romania
}

\begin{abstract}
Large volumes of waste water resulting from zoo technical complexes and high load of nutrients and easily degradable organic matter make the wastewater a powerful pollutant for the emissions in which it is discharged. The research is conducted to make a valorification of waste water and sludge as organic manure from SC BELSUINTEST SRL distributed in 5 fields. the characteristic of the soil of these fields (Humus, pH, total $\mathbf{N}$, mobile $P$, mobile $K$ ) showed no restrictions on the agricultural land application of waste water and sludge from SC BELSUINTEST SRL, the cation exchange capacity ( $\left.\mathrm{T}-\mathrm{NH}_{4}\right)$ indicating that the soil will react very well to the application of residual products (waste water and sludge).
\end{abstract}

Keywords: organic manure, waste water, water pollution, environment, soil fertility.

\section{INTRODUCTION}

Organic manure:

The organic matter is an important source of plant nutrients in addition to its role of providing organic colloidal of soil. It has water holding capacity, ion exchange capacity and soil fertility as its regulates the soil water and air supply, which in turn control the rate at which nutrients are absorbed by the roots "Hussain A., et al. 2017)".

The addition of organic materials such as crop residues, animal manures, green manures to soils have a direct effect on soil organic matter content, can improve soil fertility, soil physical characteristics "Roy S; Kashem A. (2014)".It helps in maintaining $\mathrm{C}: \mathrm{N}$ ratio in the soil "Chandra $\mathbf{K}, \mathbf{( 2 0 0 5 )}$ ". amendments raised soil $\mathrm{pH}$ and $\mathrm{EC}$, regardless of the type of manure used. Manuring lowered the concentrations of Mehlich-3 extractable $\mathrm{Ca}, \mathrm{P}, \mathrm{Mn}$ and
$\mathrm{Si}$ in all soils and decreased the concentration of $\mathrm{Mg}$ in the Ultisol and Oxisol. However, manure amendment led to increases in the concentrations of $\mathrm{Mg}$ and $\mathrm{K}$ in the Andisol. Organic amendments caused a decrease in $\mathrm{KCl}$ extractable $\mathrm{Al}$. "Ortiz Escobar M.E., Hue N.V. (2008)" The accurate amount of manure could efficiently be calculated from precise measurement of nutrient mineralization without loss of yield and increased risk of environmental pollution. The suitability of organic materials as fertilizer depends to a great extent on its rapidity of mineralization and liberating the nutrients present in them "Roy S., Kashem A. (2014)" The importance and, in some cases, the major problems associated with organic fertilizers, deserve special mention in a review of environmental impacts caused by animal husbandry in Europe, the "FAO/ECE (1991)" reported the following major categories of impacts:

- Fertilization of surface waters, both as a result of direct discharges of manure and as a consequence of nitrate, phosphate and potassium being leached from the soil.

- Contamination of the groundwater as a result of leaching, especially by nitrate. Phosphates are less readily leached out, but in areas where the soil is saturated with phosphate this substance is found in the groundwater more and more often.

- Surface waters and the groundwater are being contaminated by heavy metals. High concentrations of these substances pose a threat to the health of man and animals. To a certain extent these heavy metals accumulate in the soil, from which they are taken up by crops. For example, pig manure contains significant quantities of copper.

- Acidification as a result of ammonia emission (volatilization) from livestock accommodation, 
manure storage facilities, and manure being spread on the land. Ammonia constitutes a major contribution to the acidification of the environment, especially in areas with considerable intensive livestock farming “Ongley E.D. (1996)".

\section{Water pollution}

A widely used definition of pollution is the introduction by man into the environment of substances or energy reliable to cause hazards to human health, harm to living resources and ecological systems "Suleiman A. (2019)". Water pollution is a global challenge that has increased in both developed and developing countries, undermining economic growth as well as the physical and environmental health of billions of people. Although global attention has focused primarily on water quantity, water-use efficiency and allocation issues, poor wastewater management has created serious water-quality problems in many parts of the world, worsening the water crisis. Global water scarcity is caused not only by the physical scarcity of the resource but also by the progressive deterioration of water quality in many countries, reducing the quantity of water that is safe to use.

Water pollution from agriculture has direct negative impacts on human health; for example, the wellknown blue-baby syndrome in which high levels of nitrates in water can cause methaemoglobinemia - a potentially fatal illness - in infants "Mateo-Sagasta J., et al. (2017)".

\section{Wastewater}

In arid and semi-arid regions, wastewater reclamation and reuse has become an important element in water resources planning "Abedi-Koupai J., et al. (2003)". This has occurred as a result of increasing fresh water scarcity, the high cost of chemical fertilizers, high nutrients in wastewater, the high cost of advanced treatment required for other applications and the availability of wastewater near agricultural lands. Wastewater possesses different biological, physical and chemical effects on the environment. In order to apply the wastewater for irrigation it should obtain the certain criteria of qualification after treatment, for parameters such as electrical conductivity (EC), total dissolved solids (TDS), and sodium adsorption ratio (SAR). Suspended materials and organic matters are also other parameters, which might be considered before application of wastewater to agricultural lands. The principal processes which affect the physical properties of the soil by using the wastewater are the salt contents and the suspended solids "AbedKoupai J., et al. (2006)".

The use of treated wastewater in agriculture benefits human health, the environment and the economy, one of the most recognized benefits of wastewater use in agriculture is the associated decrease in pressure on freshwater sources. Thus wastewater serves as an alternative irrigation source "Jaramillo M.F., et al. (2017)".

the reuse practice is accompanied by a number of benefits relating to the enhancement of water balances and soil nutrition by the nutrients existing in the treated effluents, a number of unanswered questions are still related to this practice "Kassinos D.F., et al. (2011)" Water quality issues that can create real or perceived problems in agriculture include nutrient and sodium concentrations, heavy metals, and the presence of contaminants such as human and animal pathogens, pharmaceuticals and endocrine disruptors "Toze S., (2006)"

\section{MATERIAL AND METHODS}

the application of waste water and sludge from SC BELSUINTEST SRL there are available 211 ha, distributed in 5 fields:

- field $1 S=33$ ha

- field $2 S=14$ ha

-field $3 \mathrm{~S}=39$ ha

-field $4 \mathrm{~S}=95$ ha

-field $5 \mathrm{~S}=30 \mathrm{ha}$

The unit has a large storage capacity, and $82,000 \mathrm{~m}^{3}$ of waste water can be stored in the Movila Verde pits. The sludge is stored on drying platforms. The unit has sufficient capacity for storing sewage and sludge. 
International Journal of Engineering Applied Sciences and Technology, 2020

Vol. 4, Issue 12, ISSN No. 2455-2143, Pages 50-58

Published Online April 2020 in IJEAST (http://www.ijeast.com)

Table 1. Chemical analysis of soil SC BELSUINTEST SRL:

\begin{tabular}{|l|l|l|l|l|l|l|l|}
\hline No & identification & depth & $\mathrm{pH}$ & $\begin{array}{l}\text { Humus } \\
\%\end{array}$ & $\begin{array}{l}\mathrm{N} \\
\text { total } \\
\%\end{array}$ & $\begin{array}{l}\mathrm{P} \\
\mathrm{mg} / \mathrm{kg}\end{array}$ & $\begin{array}{l}\mathrm{K} \\
\mathrm{mg} / \mathrm{kg}\end{array}$ \\
\hline 1 & Bf 47.1 & $0-20$ & 7.91 & 3.67 & 0.199 & 20 & 171 \\
\hline 2 & Bf 47.2 & $0-20$ & 8.06 & 3.67 & 0.219 & 44 & 144 \\
\hline 3 & Bf 47.3 & $0-20$ & 8.05 & 3.85 & 0.199 & 19 & 173 \\
\hline 4 & Bf 47.4 & $0-20$ & 7.92 & 3.49 & 0.176 & 22 & 127 \\
\hline 5 & Bf 47.5 & $0-20$ & 8.04 & 3.38 & 0.182 & 13 & 155 \\
\hline 6 & Bf 47.6 & $0-20$ & 8.05 & 3.08 & 0.178 & 17 & 146 \\
\hline 7 & Bf 47.7 & $0-20$ & 7.92 & 3.43 & 0.184 & 26 & 220 \\
\hline 8 & Bf47.8 & $0-20$ & 8.07 & 2.96 & 0.158 & 14 & 159 \\
\hline 9 & Bf 47.9 & $0-20$ & 8.05 & 3.43 & 0.182 & 16 & 148 \\
\hline 10 & Bf 64.1 & $0-20$ & 8.19 & 2.72 & 0.157 & 5 & 109 \\
\hline 11 & Bf 64.2 & $0-20$ & 8.25 & 2.37 & 0.155 & 6 & 127 \\
\hline 12 & Bf 64.3 & $0-20$ & 7.85 & 4.62 & 0.237 & 28 & 215 \\
\hline 13 & Bf 64.4 & $0-20$ & 7.86 & 4.80 & 0.265 & 52 & 215 \\
\hline 14 & Bf 64.5 & $0-20$ & 7.31 & 4.50 & 0.267 & 123 & 429 \\
\hline 15 & Bf 64.6 & $0-20$ & 7.89 & 2.84 & 0.171 & 32 & 178 \\
\hline 16 & Bf 64.7 & $0-20$ & 8.21 & 1.95 & 0.117 & 10 & 190 \\
\hline 17 & Bf64.8 & $0-20$ & 7.24 & 5.03 & 0.327 & 166 & 793 \\
\hline 18 & Bf 181.1 & $0-20$ & 7.37 & 4.03 & 0.222 & 15 & 144 \\
\hline 19 & Bf 181.2 & $0-20$ & 7.97 & 3.08 & 0.176 & 9 & 140 \\
\hline 20 & Bf 181.3 & $0-20$ & 7.96 & 3.32 & 0.163 & 11 & 146 \\
\hline & & & & & & & \\
\hline
\end{tabular}

The data presented in (Table 1) shows that $\mathrm{pH}$ values vary between 7.24 and 8.25 , fits in low alkaline soil class. The data show that there are no restrictions on the agricultural land application of waste water and sludge from SC BELSUINTEST SRL. (Table 1) shows average values of humus, ranging from 1.95 to $5.03 \%$, the values belonging to the small and medium classes, indicating the necessity of application of organic fertilizers. Particular attention will be paid to physical blocks where the humus content falls into the low level of supply, where we must apply the puddings as a priority. In the area of distribution of sewage and sludge, care should be taken to ensure that plant debris is chopped and spread to the surface of the soil. The values of the total nitrogen level shown in (Table 1) range from 0.117 to $0.267 \%$, falling within the small and large supply classes, according to chart 3 , but most of the surfaces have a medium supply level. The physical block 64.8 has been used for the application of residual products as it has a higher content of organic matter and nutrients. Total nitrogen values do not limit the application of waste water and sludge from SC BELSUINTEST SRL to agricultural land.

Higher variability is the level of phosphorus supply, with values ranging from 5 to $166 \mathrm{mg} / \mathrm{kg}$, falling in the supply classes from very low to very good land. With the exception of physical blocks 64.8 and 64.5 which are very well supplied, the other blocks have large amounts of organic fertilizer (sewage sludge and sludge) to provide at least a middle level supply of mobile phosphorus. It should consider that wastewater and sludge from pigs contain fast-moving mobile phosphorus for plants, higher $\mathrm{pH}$ values (over 7.5) tend to block phosphorus mobility in soil.

The values of mobile potassium (Table 1) oscillates between 127 and $793 \mathrm{mg} / \mathrm{kg}$. highlighting a level of coverage from weak to very good. It is obvious that two physical blocks (64.8 and 64.5) have been fertilized with zoo technical residues. In the future, the application of residual products will be attempted, especially on weaker soils with organic matter and nutrients, so that in time it is possible to uniform the supply of sole. With a capacity of about 25,000 pig heads, about $45,000 \mathrm{~m}^{3}$ / year of waste water and about $2900 \mathrm{~m}^{3} / \mathrm{m}$ will be discharged from the complex.

Table 2. Cation exchange Capacity and Residual conductivity.

\begin{tabular}{|l|l|l|l|l|}
\hline $\begin{array}{l}\text { Number } \\
\text { of } \\
\text { sample }\end{array}$ & $\begin{array}{l}\text { identifica } \\
\text { tion }\end{array}$ & depth & $\begin{array}{l}\text { T-NH4 } \\
\mathrm{mg} / 100 \mathrm{~g}\end{array}$ & $\begin{array}{l}\text { Residual. } \\
\text { conductivit } \\
\text { y mg/100g }\end{array}$ \\
\hline 1 & Bf 47.1 & $0-20$ & 24.93 & 49 \\
\hline 2 & Bf 47.2 & $0-20$ & 25.95 & \\
\hline 3 & Bf 47.3 & $0-20$ & 23.92 & \\
\hline 4 & Bf 47.4 & $0-20$ & 2.44 & 33 \\
\hline 5 & Bf 47.5 & $0-20$ & 24.93 & \\
\hline 6 & Bf 47.6 & $0-20$ & 22.39 & \\
\hline 7 & Bf 47.7 & $0-20$ & 23.41 & 39 \\
\hline 8 & Bf47.8 & $0-20$ & 22.39 & \\
\hline 9 & Bf 47.9 & $0-20$ & 23.41 & \\
\hline 10 & Bf 64.1 & $0-20$ & 22.39 & 44 \\
\hline 11 & Bf 64.2 & $0-20$ & 20.35 & \\
\hline 12 & Bf 64.3 & $0-20$ & 26.46 & \\
\hline 13 & Bf 64.4 & $0-20$ & 26.46 & \\
\hline 14 & Bf 64.5 & $0-20$ & 28.50 & 121 \\
\hline 15 & Bf 64.6 & $0-20$ & 21.37 & \\
\hline 16 & Bf 64.7 & $0-20$ & 19.34 & \\
\hline 17 & Bf64.8 & $0-20$ & 28.50 & 240 \\
\hline 18 & Bf 181.1 & $0-20$ & 22.39 & \\
\hline 19 & Bf 181.2 & $0-20$ & 23.92 & 35 \\
\hline 20 & Bf 181.3 & $0-20$ & 24.42 & \\
\hline
\end{tabular}

The cation exchange capacity $\left(\mathrm{T}-\mathrm{NH}_{4}\right)$ (table 2 ) varies between 19.34 and $28.50 \mathrm{me} / 100 \mathrm{~g}$ of soil, indicating that the soil will react very well to the application of residual products (waste water and sludge from SC BELSULTTEST SR). Conductivity test values oscillates between 33 and $240 \mathrm{mg} / 100 \mathrm{~g}$.

The high values (121 and $240 \mathrm{mg} / 100 \mathrm{~g}$ ) were registered in 2 sole, with high values for organic matter 
and nutrients as well, which have been used so far to produce zoo technical waste products.

On soy 64.8 Where the conductive residue values reached $240 \mathrm{mg} / 100 \mathrm{~g}$, pork sludge will also be used, and if it is possible to irrigate, the watering standard will be increased by $100-120 \mathrm{~m}^{3} /$ ha to be ensures the tendency of the salt to accumulate in the soil.

Table 3. presents the data on the loading of heavy metals $(\mathrm{Zn}, \mathrm{Cu}, \mathrm{Pb}, \mathrm{Cd}, \mathrm{Cr}$ and $\mathrm{Ni}$ ) of the soils under the administration of SC BELSUINTEST SRL. (depth 0-20 cm).

\begin{tabular}{|l|l|l|l|l|l|l|}
\hline $\begin{array}{l}\text { numbe } \\
\text { rof } \\
\text { sampl } \\
\mathrm{e}\end{array}$ & $\begin{array}{l}\mathrm{Zn} \\
\mathrm{mg} /\end{array}$ & $\begin{array}{l}\mathrm{Cu} \\
\mathrm{kg} /\end{array}$ & $\begin{array}{l}\mathrm{Pb} \\
\mathrm{mg} / \\
\mathrm{kg}\end{array}$ & $\begin{array}{l}\mathrm{Cd} \\
\mathrm{mg} / \\
\mathrm{kg}\end{array}$ & $\begin{array}{l}\mathrm{Cr} \\
\mathrm{mg} / \\
\mathrm{kg}\end{array}$ & $\begin{array}{l}\mathrm{Ni} \\
\mathrm{mg} / \\
\mathrm{kg}\end{array}$ \\
\hline 1 & 51.9 & 22.2 & 28 & 0.07 & 30.7 & 34.2 \\
\hline 4 & 46.8 & 21.1 & 17.9 & 0.07 & 29.4 & 32.7 \\
\hline 7 & 45.5 & 22.6 & 17.9 & 0.02 & 30.4 & 31.6 \\
\hline 10 & 42.2 & 18.7 & 17.9 & 0.09 & 15.4 & 29.3 \\
\hline 14 & 60.1 & 24.7 & 17.9 & 0.17 & 29.4 & 31.3 \\
\hline 17 & 93.7 & 36.7 & 17.9 & 0.17 & 34.8 & 32 \\
\hline 19 & 39.8 & 19.9 & 7.8 & 0.17 & 19.2 & 31.9 \\
\hline
\end{tabular}

Zinc values oscillated between 42.2 and $93.7 \mathrm{mg} / \mathrm{kg}$ within normal limits. The highest value $(93.7 \mathrm{mg} / \mathrm{kg})$ was recorded on soil which was fertilized with pig products for a long time, which indicates that mineral complexes containing zinc are used in the complex. All values fall within the normal range, and these higher values are within the range they are useful for avoiding zinc deficiencies. Copper values oscillated between 18.7 and $36.5 \mathrm{mg} / \mathrm{kg}$ within the normal range. Copper in the form of copper sulphate or copper oxide at a level of $250 \mathrm{ppm}$ in ration is used as a growth stimulator and alters the bacterial level in the intestines of the animals. It was estimated that $80 \%$ of the ingested copper was excreted and that the biological treatment of the residues was limited when $36 \mathrm{ppm}$ copper was added to the ration. The $\mathrm{Pb}, \mathrm{Cd}, \mathrm{Cr}$ and $\mathrm{Ni}$ values have oscillated within normal limits, with no restrictions or special attention in the distribution of livestock residues on farmland.

Table 4. Soil texture and carbonate content (depth 0-20 cm)

\begin{tabular}{|l|l|l|l|l|l|}
\hline $\begin{array}{l}\text { No of } \\
\text { sample }\end{array}$ & \multicolumn{3}{|l|}{$\begin{array}{l}\text { Granule fractions in } \mathrm{mm} \\
\text { mineral parts of soil }\end{array}$} & $\begin{array}{l}\text { Carbonate } \\
\%\end{array}$ \\
\cline { 2 - 5 } & $\begin{array}{l}\text { Coarse } \\
\text { sand }\end{array}$ & $\begin{array}{l}\text { Fine } \\
\text { sand }\end{array}$ & silt & clay & \\
\hline & $2-0.2$ & $0.2-$ & 0.02 & 0.002 & \\
& & 0.02 & & & \\
\hline
\end{tabular}

\begin{tabular}{|l|l|l|l|l|l|}
\hline 1 & $\mathbf{0 . 2}$ & $\mathbf{4 5 . 7}$ & $\mathbf{3 1 . 6}$ & $\mathbf{2 2 . 5}$ & 1.4 \\
\hline 2 & & & & & 1 \\
\hline 3 & & & & & 0.8 \\
\hline 4 & $\mathbf{0 . 1}$ & $\mathbf{4 4 . 9}$ & $\mathbf{3 1 . 1}$ & $\mathbf{2 3 . 9}$ & 0.4 \\
\hline 5 & & & & & 1.2 \\
\hline 6 & & & & & 2.3 \\
\hline 7 & $\mathbf{0 . 1}$ & $\mathbf{4 6 . 9}$ & $\mathbf{3 1 . 3}$ & $\mathbf{2 1 . 7}$ & 0.8 \\
\hline 8 & & & & & 0.4 \\
\hline 9 & & & & & 1.6 \\
\hline 10 & $\mathbf{0 . 1}$ & $\mathbf{5 2 . 0}$ & $\mathbf{2 5 . 5}$ & $\mathbf{2 2 . 4}$ & 6.2 \\
\hline 11 & & & & & 6 \\
\hline 12 & & & & & 0.2 \\
\hline 13 & & & & & 0.6 \\
\hline 14 & $\mathbf{0 . 2}$ & $\mathbf{4 4 . 8}$ & $\mathbf{3 0 . 0}$ & $\mathbf{2 5 . 0}$ & 0.4 \\
\hline 15 & & & & & 3.3 \\
\hline 16 & & & & & 8 \\
\hline 17 & $\mathbf{0 . 4}$ & $\mathbf{4 7 . 7}$ & $\mathbf{2 8 . 8}$ & $\mathbf{2 3 . 1}$ & 1.6 \\
\hline 18 & & & & & 0.2 \\
\hline 19 & $\mathbf{0 . 1}$ & $\mathbf{4 5 . 2}$ & $\mathbf{3 1 . 1}$ & $\mathbf{2 3 . 6}$ & 0.6 \\
\hline 20 & & & & & 0.6 \\
\hline
\end{tabular}

The data presented in Table 4 on the granulometric fractions of the soil samples taken from the land administered by SC BELSUINTEST SRL have soils with clay loam texture. The soil has a low carbonate content.

\section{Characterization of waste water}

Table 5. presents the chemical characteristics of wastewaters from BELSUINTEST SRL.

\begin{tabular}{|c|c|}
\hline Number & 1 \\
\hline identification & $\begin{array}{l}\text { Waste water from } \\
\text { pits }\end{array}$ \\
\hline $\begin{array}{ll}\text { SAR } & \text { me/l. }\end{array}$ & 4.54 \\
\hline Residue conductivity mg / 100g & 3936 \\
\hline pH & 8.26 \\
\hline $\mathrm{NO}_{3} \mathrm{mg} / \mathrm{kg}$ & 7 \\
\hline $\mathrm{N}-\mathrm{NH}_{4} \mathrm{mg} / \mathrm{kg}$ & 184 \\
\hline Total N (Keldahel ) mg/l & 212 \\
\hline P mg/l & 26 \\
\hline K mg/l & 1561 \\
\hline $\mathrm{Cu} \mathrm{mg} / \mathrm{l}$ & 0.51 \\
\hline Cr mg/l & - \\
\hline Mn mg/l & 0.50 \\
\hline Ni mg/l & 0.16 \\
\hline $\mathbf{P b ~ m g / l}$ & - \\
\hline Zn mg/l & 212 \\
\hline
\end{tabular}


3.2.3. Characterization of pork sludge for use as a fertilizer on agricultural lands administration of SC BELSUINTEST SRL.

Table 6. Characterization of pork sludge

\begin{tabular}{|l|l|l|}
\hline Number & 2 & 3 \\
\hline identification & $\begin{array}{l}\text { Zoo technic } \\
\text { garbage }\end{array}$ & $\begin{array}{l}\text { Zoo technic } \\
\text { garbage }\end{array}$ \\
\hline Moisture \% & 18.1 & 27.8 \\
\hline $\begin{array}{l}\text { Residue } \\
\text { conductivity } \\
\text { mg / 100g }\end{array}$ & 999 & 1085 \\
\hline $\mathbf{p H}$ & 6.59 & 6,94 \\
\hline NO $\mathbf{~ m g / k g ~}$ & 21 & 90 \\
\hline N-NH4 mg/kg & 284 & 229 \\
\hline $\begin{array}{l}\text { Total N } \\
\text { (Keldahel ) } \\
\text { \% }\end{array}$ & 1.59 & 1.44 \\
\hline $\mathbf{P \%}$ & 0.93 & \\
\hline K \% & 0.38 & 0.56 \\
\hline OM \% & 85 & 70.2 \\
\hline Cu mg/kg & 113 & 274 \\
\hline Cr mg/kg & - & - \\
\hline Mn mg/kg & 460 & 677 \\
\hline Ni mg/kg & 10.5 & 12.5 \\
\hline Pb mg/kg & - & - \\
\hline Zn mg/kg & 126.4 & 358.9 \\
\hline
\end{tabular}

\section{RESULTS}

Valorification of waste water

\section{The data highlights the following:}

Residue conductivity was $3936 \mathrm{mg} / \mathrm{l}$, and sodium absorption (SAR) values were $4.54 \mathrm{me} / \mathrm{l}$. Following these values, in line with the Richards chart for irrigation water classification, this water falls within the C4S1 class, a water with high salinization hazard but with a low alkalinity hazard.

According to the Florea diagram for assessing the quality of irrigation water, the analyzed wastewater falls into the Iv class as acceptable-unsatisfactory irrigation water; acceptable for most crop plants, especially on light and medium soils with good drainage; unsatisfactory for sensitive plants and heavy soils or poor drainage; as a rule, periodic washing and / or gypsum amendment are required.
The physio-chemical characteristics of the soils under the management of SC BELSUINT EST SRL highlight that these are suitable for the distribution of waste water, having a soft, medium texture and a good drainage.

Even if the level of salt in the wastewater is quite high, the risk of accumulation in the soil is low, due to the reduced recommended wastewater use. The danger of land sludge is lowered. The distribution of these waters on the agricultural land should be uniform, as its concentration in the depressions can lead to the destruction of crops due to the combined effects of excess water, high salinity and high concentrations of ammonia.

In view of the characteristics of these waters, it is recommended that they be used only for crops not used directly in human food, provided that irrigation ceases at least three weeks before the crop is harvested. The same interdiction period shall also be observed in the case of irrigation of fodder plants which are used as green meals in animal feed, the interval being reduced to 2 weeks if the plants are harvested for silage.

The safest use is outside the growing season of crops, especially applied to the soil on which the vegetal remains have been chopped, because this would make good use of the soluble nitrogen and would increase the humus content of ground.

For use as irrigation water after the system for maintaining the minimum moisture limit in the soil it is necessary to dilute with conventional clean water to avoid saline and ammonia stress. Ammoniac stress occurs especially in soybeans, so it is desirable that this plant is not irrigated (watered with wastewater during vegetation). Soybeans benefit from nutrients and water from the soil if applied before the sowing of the crop.

During vegetation the application of waste water can be done on furrows.

In the multitude of studies, we have conducted in the country, and literature data, it shows that production increases with the amount of applied wastewater, irrigation rules ranging from 1000 to $5000 \mathrm{~m}^{3} /$ ha.

The $\mathrm{pH}$ of the analyzed waste water is high $(8,26)$, which highlights the presence of large amounts of ammonium salts.

Nitric nitrogen values are reduced (7 $\mathrm{mg} / 1)$, which shows a low profile wash risk.

Ammonium nitrogen values are high $(184 \mathrm{mg} / \mathrm{l})$, representing $45.6 \%$ of total nitrogen. 


\section{International Journal of Engineering Applied Sciences and Technology, 2020 \\ Vol. 4, Issue 12, ISSN No. 2455-2143, Pages 50-58 \\ Published Online April 2020 in IJEAST (http://www.ijeast.com)}

Ammonia losses due to volatilization in the case of application of wastewater on the surface of the soil vary greatly with the soil and liquid $\mathrm{pH}$, air temperature and air movement.

Increasing the $\mathrm{pH}$ of soil and wastewater (as is the case here) leads to a very high loss of N-NH4 (about 70\%). Wastewater had a very high potassium content (1561 $\mathrm{mg} / \mathrm{l})$ and low phosphorus content (26 mg / P).

The level of heavy metals has fallen within the normal range for wastewater. They come from a pig breeding complex and do not restrict the doses of wastewater that can apply on agricultural land.

Under the current conditions, with the application of the Nitrates Directive, the applied water norm per hectare is limited by the nitrogen content, and it is not allowed to apply over $170 \mathrm{~kg} \mathrm{~N} /$ ha in our case from the wastewater and if the agrochemical study shows that the necessary plant to achieve a certain level of production is greater, the difference will be applied by fertilization with mineral fertilizers. The wastewater dose applied to agricultural land (Nt) is determined according to the crop nitrogen $(\mathrm{Nc})$, available nitrogen (Ns), nitrogen lost by volatilization (Nv), washing $(\mathrm{Nl})$, denitrification $(\mathrm{Nd})$ and surface leakage $(\mathrm{Ne})$

$\mathrm{Nt}=\mathrm{Nc}-(\mathrm{Ns}+\mathrm{Nv}+\mathrm{Nd}+\mathrm{Nl}+\mathrm{Ne})$.

According to the IPCC data, for pigs reared in the complex in Eastern Europe nitrogen losses to excreted are $55 \%$. According to US literature, ammoniac nitrogen losses from waste water are $15 \%$, and those by denitrification, leaching and leakage $35 \%$, thus a total of $50 \%$.

Given the $\mathrm{pH}$ of water and soil that can increase ammonia nitrogen losses to $70 \%$, we could estimate a possible $55 \%$ ammonia loss, a value recommended by the IPCC and accepted by the CE.

Under these conditions, for the current set of waste water analyzes, the wastewater standard that can be applied to agricultural land could range from $422 \mathrm{~m}^{3} /$ ha to $654 \mathrm{~m}^{3} /$ ha. Considering the high water deficit in Constanta County we recommend the application of doses of 400- $660 \mathrm{~m}^{3} /$ ha. Ideally, the waste water should be applied to the land on which the chopped vegetal remains have been left, as this will help to mineralize them, increase the humus content in the soil, and there will no longer be a need for the mineralization of vegetable residues to apply mineral fertilizers nitrogen ( $10 \mathrm{~kg}$ nitrogen / tonne of straw) to avoid hunger of nitrogen. It is usually recommended to apply $50 \mathrm{~kg}$ a.c. nitrogen / ha for the mineralization of organic residues and avoid hunger for nitrogen.
SC BELSUINTEST SRL has a land area of 211 ha, which can be used for waste products, wastewater $\left(45,000 \mathrm{~m}^{3}\right.$ / year $)$ and sludge $\left(2900 \mathrm{~m}^{3} /\right.$ year $)$.

For the storage of wastewater, the complex has battens with enormous storage capacity: $82,000 \mathrm{~m}^{3}$.

Admitting that $400-600 \mathrm{~m}^{3} /$ ha of wastewater is applied at a volume of about $45,000 \mathrm{~m}^{3}$ / year of waste water is needed "(75-112 ha) Only 99 - 136 hectares remain for the application of the sludge sufficient to comply with the dose of $170 \mathrm{~kg} /$ ha nitrogen / year.

By observing recommended doses (400-600 $\left.\mathrm{m}^{3} / \mathrm{ha}\right)$, nutrients and water will be better recovered and the risk of nitrate- nitrogen leaching to groundwater will be reduced. In the conditions of irrigation and fertilization with waste water it is necessary to restore the agrochemical study to 4-5 years in order to appreciate the evolution of the soil quality and if it is necessary to correct the doses of applied organic and mineral fertilizers.

If the land is irrigated, irrigating may be in the range $400-600 \mathrm{~m}^{3} / \mathrm{ha}$ (average $500 \mathrm{~m}^{3} / \mathrm{ha}$ ) and the remainder of the irrigating will be with clean water.

For normal production $(6000-6500 \mathrm{~kg} / \mathrm{ha}$ of wheat and $7500-8000 \mathrm{~kg} / \mathrm{ha}$ of corn), it is necessary for the soils irrigated with waste water to apply two fractions and mineral fertilizers in the dose of $\mathrm{N}_{120} \mathrm{P}_{20-80} \mathrm{~K}_{20-60}$.

$80 \mathrm{~kg}$ Ps.a / ha / year, will be applied on poorly supplied sole

$60 \mathrm{~kg}$ Ps.a / ha / year, on the middle ones.

$40 \mathrm{~kg}$ Ps.a / ha / year on well-ones.

$20 \mathrm{~kg}$ Ps.a / ha / year very well supplied.

Fertilization with $\mathrm{K}$ minerals will be as follows:

- On well-supplied sole, it is estimated that sufficient $\mathrm{K}$ is derived from organic fertilization; on wellsupplied soils, $20 \mathrm{~kg}$ Ps.a / ha / year is recommended.

On middle supplying soils, $40 \mathrm{~kg} \mathrm{~K} \mathrm{s.a} \mathrm{/} \mathrm{ha} \mathrm{/} \mathrm{year} \mathrm{is}$ recommended, and $60 \mathrm{~kg} \mathrm{Ks.a/ha/year} \mathrm{will} \mathrm{be}$ applied on low-supply soils. And The same NPK $\left(\mathrm{N}_{120}\right.$ $\mathrm{P}_{20-80} \mathrm{~K}_{20-60}$ ) scheme for surfaces will be fertilized with sludge.

Valorification of sludge results from
BELSUINTEST complex The data presented in Table 10 highlights the following: 
- The sludge from SC BELSUINTEST SRL has a moisture content of $18.1-27.8 \%$ (22.95\% on average) which allows it to be spread evenly on the ground.

- the conductive residue values are 999-1085 mg / 100 g s.u. (on average $1042 \mathrm{mg} / 100 \mathrm{~g} \mathrm{su}$ ), which does not impose restrictions on fertilizer use;

- The pH had values of 6.59 and 6.94 (on average 6.76), thus slightly acidic, values which allow use as fertilizer without other treatments;

- nitrate- nitrogen values were 21 and $90 \mathrm{mg} / \mathrm{kg}$ (mean $55 \mathrm{mg} / \mathrm{kg}$ ) without imposing restrictions on application to farmland;

- ammoniac nitrogen values were 264 and $229 \mathrm{mg} / \mathrm{kg}$ (mean $246 \mathrm{mg} / \mathrm{kg}$ ), which indicates risks of volatile loss and requires its incorporation as much as possible fast if it can not be incorporated directly;

- total nitrogen values were 1.69 and $1.44 \%$ (on average $1.56 \%$ ), being assessed as normal;

- total phosphorus values were 0.93-1.55 \%, being assessed as high, offering the hope that fertilization with pork sludge will improve the general level of phosphorus supply of the soil, especially since the risk of washing on the profile is very reduced;

- Potassium values have been reduced (0.38-0.56\%, not imposing any restrictions on agricultural use of sludge;

- the pudding sludge contains high organic matter (70.2-85.0\%) which recommends it as a very good organic fertilizer especially on soils with $\mathrm{pH}$ above 7 , as is the case with the surfaces administered by SC BELSUINTEST SRL;

- Chromium values. manganese, nickel and lead fall into normal values, without restricting the use of pork sludge;

- Copper values (113-274 mg / kg s.u. of sludge) are higher than those in non-fertilized soils with pork manure in the area and show the presence in the copper mineral premixes for pigs. However, the values are far from the maximum allowable concentrations of heavy metals in sludge intended for use in agriculture (limit values of $500 \mathrm{mg} / \mathrm{kg}$;

Zinc hazards ranged from 1264-3589 mg / kg (mean $2416 \mathrm{mg} / \mathrm{kg}$ ) showing that pork sludge is a very good source in this microelement, especially since sludge is applied to soils that have carbonate from the surface and have high $\mathrm{pH}$ values, which creates favorable conditions for zinc deficiency. It is known that in soils with $\mathrm{pH}$ above 7 the mobility of copper and zinc is greatly reduced and there is a risk of deficiency. In fact, fining with calcium carbonate is one way of reducing the mobility of these elements in polluted areas.

To comply with the Nitrate Directive for application of only $170 \mathrm{~kg} / \mathrm{ha}$ of nitrogen from manure we recommend application on agricultural land of 40-50t / ha of sludge per year, although if we take into account the total nitrogen content (1.7185-1.4719\%) would allow the application of 98-115 $\mathrm{t} / \mathrm{ha}$. We recommend doses of 40-50t / ha to organically fertilize the entire area they administer. especially applying to lowcontent areas in organic matter and nutrients.

The 25,000 pigs annually account for about 2900 $\mathrm{m}^{3} /$ sludge with $70 \%$ humidity.

At a dose of $50 \mathrm{t} /$ ha of sludge, it is necessary to distribute 58 ha.

Periods of prohibition for the application of organic fertilizers on agricultural land.

Periods of prohibition for field application of fertilizers are defined by the time the average air temperature falls below $5{ }^{\circ}$ C. This interval corresponds to the period when the requirements of agricultural crops towards nutrients are reduced or when the risk of percolation / surface leakage is high.

Under the pedoclimatic conditions of Romania, periods of high percolation or leakage from the cold interval (spring autumn) are included in the time interval when the average air temperature is below $5^{\circ}$ C. Generalizations based on the multiannual climate data as well as on the traditional agricultural calendar led to the establishment of dates for the beginning and the end of the application of fertilizers differentiated according to land use (arable, pasture), type of crops (autumn crops, spring crops ) and type of fertilizer (mineral, organic solid and organic liquid).

Manure storage capacities must be projected for a period longer than one month from the ban on the application of fertilizers. The prohibition period for the application of manure on land will be in line with the prohibition period for the application of manure on the land will be in line with the Code of Good Agricultural Practices.

\section{CONCLUSION}

The application of waste water and sludge 
can be a solution for crops amendments of water and nutrients in soils with no restrictions of waste water and sludge applications.

\section{Nitrate}

To comply with the Nitrate Directive for application of only $170 \mathrm{~kg} / \mathrm{ha}$ of nitrogen from manure we recommend application on agricultural land of 40-50t / ha of sludge per year.

\section{phosphorus}

fertilization with pork sludge will improve the general level of phosphorus supply of the soil, especially since the risk of washing on the profile is very reduced.

\section{Microelement}

pork sludge is a very good source of microelement, especially since sludge is applied to soils that have carbonate from the surface and have high $\mathrm{pH}$ values, which creates favorable conditions for zinc deficiency. Chromium values. manganese, nickel and lead fall into normal values, without restricting the use of pork sludge.

\section{period for the application}

Under the pedoclimatic conditions of Romania, the prohibition period for the application of manure on land will be in line with the Code of Good Agricultural Practices.

\section{REFERENCES}

1. Suleiman A. (2019). MONITORING GROUND WATER POLLUTION IN (CONSTANTA) PECINEAGA ZONE. International Journal of Engineering Applied Sciences and Technology, 2019 Vol. 4, Issue 2, ISSN No. 2455-2143, (Pages 24-33).

2. Mateo-Sagasta J., Zadeh S.M.,Turral H., Bruke J. (2017). Water pollution from agriculture: a global review Published by the Food and Agriculture Organization of the United Nations Rome (FAO), 2017 and the International Water Management Institute on behalf of the Water Land and Ecosystems research program Colombo, 2017.

3. Jaramillo M.F., Restrepo I. (2017). Wastewater Reuse in Agriculture: A Review about Its Limitations and Benefits. Sustainability 2017, 9, 1734; doi:10.3390/su9101734.

4. Hussain A., Priyadarshi M., Said S., Suraj N., (2017). Effect of Wastewater on the Soil and Irrigation Process: A Laboratory
Study.j.Geographical studies,1(1),(Pages4655),2017.

5. Roy S., Abul Kashem M.D, (2014). Effects of Organic Manures in Changes of Some Soil Properties at Different Incubation Periods, Open Journal of Soil Science, 2014, 4, (pages81-86) Published Online March 2014 in SciRes http://www.scirp.org/journal/ojss http://dx.doi.org/10.4236/ojss.2014.43011

6. Fatta-Kassinos D., Kalavrouziotis I.K., Koukoulakis P.H., Vasquez M.I., (2011). The risks associated with wastewater reuse and xenobiotics in the agroecological environment. Science of The Total Environment, Volume 409, Issue 19, 1 September 2011, (Pg3555-3563).

7. Ortiz Escobara M.E., Hueb N.V., (2008).Temporal changes of selected chemical properties in three manure Amended soils of Hawaii. Bioresource Technology, Volume 99, Issue 18, December 2008, (Pages 8649-8654).

8. Toze S. (2006). Reuse of effluent waterbenefits and risks. Agricultural Water Management, Volume 80, Issues 1-3, 24 February 2006, (Pages 147-159).

9. Abedi-Koupai J., Mostafazadeh-Fard B., Afyuni M., Bagheri M.R. (2006). Effect of treated wastewater on soil chemical and physical properties in an arid region. PLANT SOIL ENVIRON., 52, 2006 (8): (Pages 335-344).

10. Chandra K., (2005). ORGANIC MANURES. Regional Centre of Organic Farming No. 34, 5th Main Road Hebbal, Banglaore-24. Released on the occasion of 10 days training programme on "Production and Quality Control of Organic Inputs" Kottayam, Kerala.

11. Abedi-Koupai J., Bakhtiarifar A. (2003). Investigation of the effect of treated wastewater on hydraulic properties of emitters in trickle irrigation system. In: 20th Eur. Region. Conf., CD Int. Workshop, Irrigation technologies and method: Research, development and testing, Montpellier, France.

12. Ongley E.D. (1996). Control of water pollution from agriculture - FAO irrigation and drainage paper 55 . Published by the Food and Agriculture Organization of the United Nations Rome (FAO), Rome, 1996. M-56,ISBN 92-5-103875-9

13. FAO/ECE. (1991). Legislation and Measures for the Solving of Environmental 
Problems Resulting from Agricultural Practices (With Particular Reference to Soil, Air and Water), Their Economic Consequences and Impact on Agrarian Structures and Farm Rationalization. United Nations Economic Commission for Europe (UNECE) and FAO, Agri/Agrarian Structures and Farm Rationalization Report No. 7. United Nations, Geneva. 